\title{
MENGENAL LEBIH DEKAT KERAPU BEBEK (Cromileptes altivelis) HASIL BUDIDAYA
}

\author{
Ida Komang Wardana dan Tridjoko \\ Balai Besar Penelitian dan Pengambangan Budidaya Laut \\ Jl. Br. Gondol, Kec. Gerokgak Kab. Buleleng, Kotak Pos 140, Singaraja, Bali 81101 \\ E-mail: genta1190@yahoo.co.id
}

\begin{abstract}
ABSTRAK
Kerapu bebek/kerapu tikus/humpback grouper (Cromileptes altivelis) merupakan salah satu komoditas perikanan budidaya laut yang memiliki nilai jual tinggi. Sebelum berkembangnya kerapu hibrid, Balai Besar Penelitian dan Pengembangan Budidaya Laut Gondol, sudah berhasil mengembangkan pembenihan ikan kerapu bebek meskipun sintasan yang diperoleh masih bervariasi. Pemantauan benih hasil budidaya sebagian besar terfokus pada pertumbuhan dan jika sudah mencapai ukuran konsumsi bisa dijual atau diekspor ke Hongkong. Sebagai institusi penelitian nampaknya masih perlu mengupas lebih detail komoditas yang dikembangkan. Beberapa catatan yang dapat diperhatikan, untuk lebih mengenal komoditas kerapu bebek, sebelum dijadikan sebagai ikon jenis ikan yang pernah memiliki masa kejayaan, karena saat ini popularitasnya relatif menurun karena ada larangan ekspor dan masuk dalam satwa CITES. Catatan tersebut antara lain; kerapu bebek selama fase yuwana (2-3 bulan) dapat dijadikan sebagai kandidat ikan hias dengan performasi bintik bintik hitam pada permukaan tubuh yang merupakan keunikan tersendiri, karena jumlah dan polanya berbeda antara satu individu dengan yang lainnya serta akan bertambah jumlahnya seiring dengan bertambahnya umur dan bobot badan. Spot/bintik hitam kemungkinan identik dengan sidik jari manusia, yang bisa digunakan untuk membedakan antara satu individu dengan individu lainnya dalam satu populasi. Gonad kerapu bebek turunan pertama (F1) dengan umur dan kisaran bobot badan yang kurang lebih sama (600-900 g), menunjukkan 95\% berada pada fase betina. Sementara pematangan dan pembentukan gonad jantan pada kerapu bebek hasil budidaya dapat dipacu dengan rangsangan hormonal dan pemberian pakan segar dengan kualitas yang baik. Dari hasil pengamatan diperoleh informasi bahwa kerapu bebek hasil budidaya dapat memijah dengan baik dan menghasilkan turunan generasi kedua (F2), akan tetapi kualitas telur dan larva yang dihasilkan masih lebih rendah bila dibandingkan dengan larva pemijahan induk alam (F0).
\end{abstract}

KATA KUNCI : kerapu bebek (Cromileptes altivelis), hasil budidaya

ABSTRACT: $\quad$ Understanding more about the cultured humpback grouper (Cromileptes altivelis). By: Ida Komang Wardana dan Tridjoko

Humpback grouper (Cromileptes altivelis), is one of mariculture commodities with high market value, to be exported to Hong Kong and other countries. Institute for Mariculture Research and Development has been succeeded to develop humpback grouper hatchery, although the survival rate still fluctuated. In addition, monitoring of the cultured seed was only focused on growth. Therefore, it is required to have more understanding about humpback grouper and several records need to be considered. First, juvenile humpback grouper (2-3 months old) can be utilized as ornamental fish. Juvenile humpback grouper exhibited unique character of the black dot on body surface with different pattern and number of the black dot among individuals. The number of the black dot increases with age and body weight. It is likely that the black dot could be used to differentiate individuals in a population. Second, 95\% of the first generation (F1) at the same age, and size of around 600-900 $\mathrm{g}$ were determined as female. Development and maturation of gonad in male could be induced by administration of hormone and the use of a good quality trash fish for feed. As a result, the cultured humpback grouper were spawned, generating the second generation (F2). However, the quality of eggs and larvae was low compared to those of the wild broodstock (F0).

KEYWORDS: $\quad$ cultured humpback grouper (Cromileptes altivelis)

\section{PENDAHULUAN}

Kerapu bebek/kerapu tikus/humpback grouper (Cromileptes altivelis) merupakan salah satu komoditas perikanan budidaya laut yang memiliki nilai jual tinggi.
Sebelum kerapu hibrid berkembang, Balai Besar Penelitian dan Pengembangan Budidaya Laut (BBPPBL) Gondol, sudah berhasil mengembangkan pembenihan ikan kerapu bebek meskipun sintasannya masih bervariasi. Pemantauan benih hasil budidaya sebagian 
besar terfokus pada pertumbuhannya dan jika sudah mencapai ukuran konsumsi mampu diekspor ke Cina dan Hongkong. Sebagai institusi penelitian masih sangat diperlukan informasi lebih detail mengenai komoditas yang dikembangkan. Dalam artikel ini akan dipaparkan beberapa hal mengenai kerapu bebek yang bersifat melengkapi informasi yang sudah ada. Selama kurun waktu 10 tahun, keberadaan kerapu bebek masih sangat tergantung dengan alam, induk-induk ataupun benih yang tersedia hampir $90 \%$ berasal dari pemijahan induk alam (F0). Sementara ketersediaan induk alam cukup sudah sangat terbatas dan sulit ditemukan terutama induk-induk ukuran yang siap untuk dipijahkan. Dengan demikian pemantauan dan seleksi calon induk dari hasil budidaya perlu dilakukan dengan tujuan untuk memperoleh data dan informasi mengenai kualitasnya, sehingga dapat dijadikan pedoman dalam perbaikan budidaya di masa yang akan datang sekaligus menjaga kelestarian populasinya di alam.

Terlaksananya penelitian evaluasi dan pembesaran benih ikan kerapu bebek F1 sebagai kandidat calon induk, secara tidak langsung akan diketahui data dan informasi mengenai kualitas secara morfologi, reproduksi dan genetik yang akan dijadikan pedoman dalam pemilihan atau produksi calon induk dari hasil kegiatan budidaya. Penelitian kerapu bebek untuk mendukung program pemuliaan sudah dilakukan secara terkontrol dan berdasarkan dari hasil penelitian yang telah dilakukan, sintasan benih yang diperoleh masih fluktuatif. Dari hasil pemijahan antara induk jantan alam (F0) dengan induk betina budidaya (F1) atau perkawinan backcross, sintasan benih yang diperoleh sampai fase juvenil masih rendah (3\%-10\%). (Tridjoko et al., 2013). Pada tahun berikutnya telah dilakukan juga evaluasi pembesaran dan pemeliharaan benih turunan pertama (F1) untuk calon induk kerapu bebek dan diperoleh hasil tentang kualitas calon induk secara morfologi, reproduksi dan genetik (Tridjoko et al., 2014a). Dari data yang diperoleh, diharapkan dapat ditemukan suatu teknik pemeliharaan/ pembesaran benih yang dipersiapkan sebagai calon induk berkualitas dari hasil budidaya. Untuk komoditas kerapu bebek telah dilakukan breeding program dengan tujuan untuk menghasilkan benih yang memiliki kualitas baik yaitu melalui selektif breeding dan cross breeding. Akan tetapi dirasa masih cukup sulit, karena untuk memperoleh generasi berikutnya membutuhkan waktu yang lama, sehingga breeding program yang diterapkan, dapat dikatakan masih dalam tahap uji pendahuluan atau belum sempurna. Selektif breeding program telah digunakan secara luas untuk menyeleksi sifat-sifat tertentu pada berbagai spesies ikan di seluruh dunia, baik pada ikan air tawar maupun air laut. Seperti yang terjadi pada catfish (Ictalurus punctatus), dilakukan seleksi individu yang tujuannya untuk meningkatkan laju pertumbuhan selama dua generasi (Brummet, 1986 dalam Tave, 1995). Kenaikan variasi genetik yang signifikan juga diperoleh pada rainbow trout (Onchorhynchus sp.), setelah diseleksi selama enam generasi melalui seleksi famili (Kincaid, 1983). Tujuan penelitian ini adalah menyajikan beberapa data kerapu bebek yang pernah dibudidayakan pada BBPPBL Gondol selama kurun waktu 10 tahun dengan tujuan untuk menghimpun informasi yang dapat dijadikan dasar pemikiran ataupun pertimbangan guna penelitian lebih lanjut.

\section{BAHAN DAN METODE}

Kegiatan ini merupakan ringkasan hasil dari beberapa penelitian kerapu bebek (C. altivelis) yang telah dilakukan pada Balai Besar Penelitian dan Pengembangan Budidaya Laut Gondol Bali. Bahan yang digunakan antara lain : induk alam kerapu bebek (F0), larva dari beberapa kali penebaran, benih generasi pertama (F1) dengan bobot awal $200 \mathrm{~g} /$ ekor dan calon induk turunan pertama (F1). Tahap kegiatan dimulai dengan pendataan jumlah populasi kerapu bebek yang ada pada BBPPBL Gondol dengan cara menghitung jumlah individu dari masing-masing populasi dan melakukan pengukuran panjang serta bobot badannya. Ikan dipelihara pada bak beton dengan sistem air mengalir 24 jam dan sebagian di keramba jaring apung (KJA). Pengamatan terhadap karakter spot/bintik hitam pada bagian abdomen ikan kerapu bebek dilakukan secara visual dengan mengambil gambar dari larva, juvenile dan benih yang memiliki umur sama, kemudian pola dan jumlah bintik hitam tersebut diamati dengan seksama. Sementara observasi terhadap abnormalitas pada kerapu bebek, dilakukan dengan cara memilih benih benih yang nampak badannya tidak normal dari setiap pembenihan, kemudian dipelihara sesuai dengan SOP pada bak yang sama sampai bobot badan berkisar 50-100 g. Ikan yang cacat permanen tersebut setelah tahap pembesaran, sampelnya dikoleksi dan sisanya dimusnahkan. Identifikasi perkembangan gonad calon induk dan induk kerapu bebek, dilihat selain melalui stripping juga dilakukan dengan proses pembedahan. Gonad yang sudah terbentuk diambil, disimpan dalam larutan formalin $10 \%$ dan dibuat preparat histologinya. Gambaran gonad betina dan jantan dapat ditentukan berdasarkan pengamatan menggunakan mikroskop dengan tingkat pembesaran 4-10x. Parameter yang diamati antara lain: karakter bintik hitam pada bagian abdomen, abnormalitas dan perkembangan gonad. Analisa data menggunakan pendekatan deskriptif, tabulasi dan dokumentasi.

\section{HASIL DAN BAHASAN}

\section{Sejarah/Kronologi Pemuliaan Kerapu Bebek}

Penelitian kerapu bebek untuk mendukung program pemuliaan sampai tahun 2013 sudah dilakukan secara terkontrol. Berdasarkan hasil penelitian sebelumnya sintasan benih yang diperoleh masih tergolong rendah (3\%-5\%). Dari hasil pemijahan antara induk alam (F0) 
dengan induk Budidaya (F1) atau perkawinan backcross, benih yang berhasil diperoleh sampai fase yuwana $(\geq 7)$ sebanyak 500 ekor (Trijoko et al., 2012). Pada tahap penelitian berikutnya, telah diperoleh benih sebagai produk biologi yang merupakan hasil perkawinan silang sebanyak 1.000 ekor dengan target ukuran panjang badan akhir penelitian yaitu $3 \mathrm{~cm}$. Akan tetapi benih yang dihasilkan tersebut belum dilengkapi dengan data tentang aspek keunggulan sebagai produk biologi. Sementara pada kegiatan penelitian yang dilakukan tahun 2014, telah dihasilkan calon induk kerapu bebek dengan kualitas morfologi yang baik, kondisi gonad yang sudah berkembang (dominasi individu betina) dan karakter genetik yang cukup baik dengan nilai heterozygositas tinggi $(0,85-0,97)$. Diketahui bahwa umur calon induk tersebut 36 bulan dengan bobot badan berkisar antara 650-1.000 g yang merupakan hasil seleksi dari benih pemijahan induk alam. Komposisi ikan kerapu bebek sampai tahun 2015, yang merupakan hasil pemeliharaan tahun-tahun sebelumnya dan sudah merupakan hasil seleksi antara lain : F0 sejumlah 22 ekor, F1 250 ekor, F2 ; 6 ekor dan F3 (hasil backcross 63 ekor). Masing-masing populasi tersebut memiliki umur, kisaran panjang, dan bobot tubuh yang tidak sama.

\section{Karakter Spot/Bintik Hitam Tubuh Kerapu Bebek}

Spot hitam atau bintik hitam pada bagian permukaan tubuh kerapu bebek, merupakan gambaran yang unik dan jumlahnya akan bertambah sejalan dengan bertambahnya umur ikan tersebut. Hal ini juga dapat dijadikan informasi spesifik dari kerapu bebek. Hasil pengamatan yang telah dilakukan dari benih kerapu bebek hasil budidaya (F1), diperoleh informasi bahwa, setiap individu memiliki jumlah dan pola bintik hitam yang berbeda pada tubuhnya, baik pada bagian sirip dada, sirip ekor, sirip punggung maupun pada sirip perut. Pada pengamatan ini, lebih difokuskan pada abdomen/badan bagian tengah dari individu ikan kerapu bebek tersebut. Spot mulai terbentuk pada umur 10 hari setelah menetas (D10) dengan tanda bintik kecil hitam pada bagian atas sirip anal (Gambar 1). Pada awal pemunculan nampak spot yang terbentuk sama baik ukuran maupun posisinya. Setelah D35 atau lebih, ditemukan adanya perbedaan, walaupun perbedaan tersebut tidak terlalu jelas. Pada Tabel 1 ditampilkan data mengenai jumlah bintik hitam pada abdomen ikan kerapu bebek turunan pertama (F1) umur tiga bulan dan sembilan bulan dengan ulangan masing masing 10 ekor.
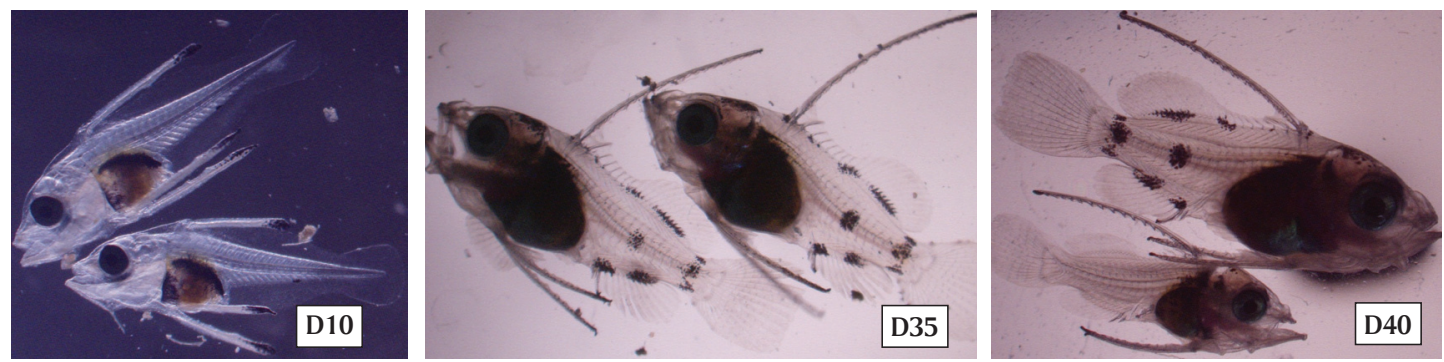

Gambar 1. Gambaran bintik hitam larva kerapu bebek hasil budidaya

Figure 1. Black spot on humpback grouper culture
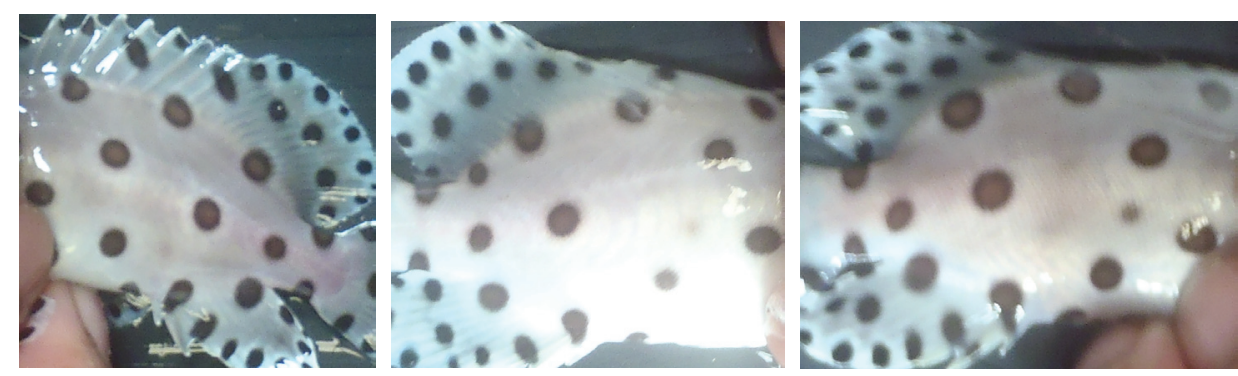

Gambar 2. Bintik hitam pada abdomen ikan kerapu bebek umur tiga bulan

Figure 2. Black spot on the abdoment of three month cultured humpback grouper
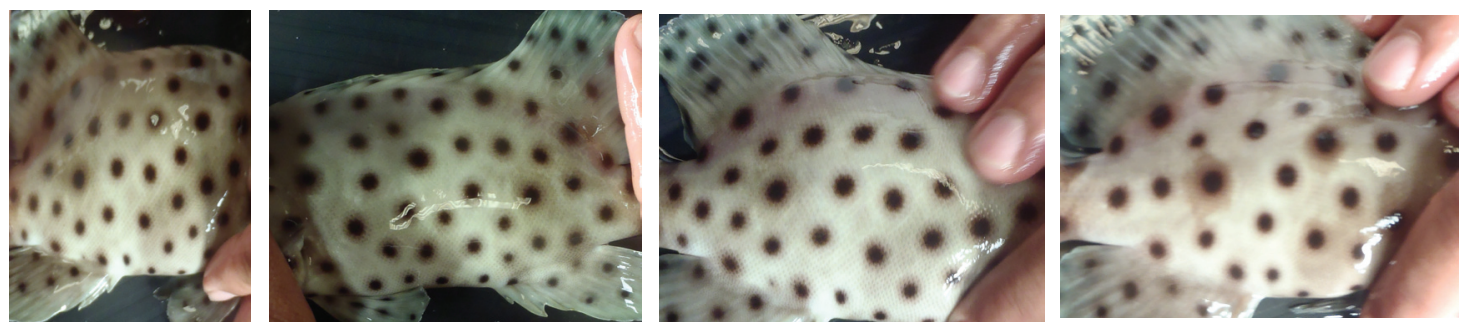

Gambar 3. Bintik hitam pada abdomen ikan kerapu bebek umur sembilan bulan

Figure 3. Black spot on the abdoment of nine month cultured humpback grouper 
Tabel 1. Jumlah bintik hitam/spot pada bagian abdomen kerapu bebek hasil budidaya

Table 1. Number of black spot on the abdoment of humpback grouper from aquaculture

\begin{tabular}{ccc}
\hline \multirow{2}{*}{$\begin{array}{c}\text { Individu } \\
\text { Individual }\end{array}$} & \multicolumn{2}{c}{$\begin{array}{c}\text { Jumlah bintik hitam (spot) } \\
\text { Number of black spot }\end{array}$} \\
\cline { 2 - 3 } & 3 bulan (months) & 9 bulan (months) \\
\hline 1 & 10 & 23 \\
2 & 11 & 27 \\
3 & 10 & 29 \\
4 & 14 & 30 \\
5 & 12 & 32 \\
6 & 14 & 36 \\
7 & 11 & 32 \\
8 & 10 & 34 \\
9 & 14 & 28 \\
10 & 12 & 24 \\
\hline
\end{tabular}

Dari Tabel 1, dapat dikatakan bahwa, setiap individu dari populasi kerapu bebek memiliki perbedaan. Hal ini memerlukan metode identifikasi yang lebih spesifik yang mengarah pada aspek genetik. Mungkin juga hal tersebut sama halnya dengan manusia yang bisa dibedakan antara satu dengan yang lainnya melalui sidik jarinya (fingerprint). Sidik jari merupakan penanda khusus yang dimiliki masing masing individu manusia dengan pola dan struktur yang hampir mirip akan tetapi tidak akan pernah sama, sekilas nampak sama, tapi dengan pengamatan yang seksama akan ditemukan letak perbedaanya. Sidik jari digunakan untuk keperluan identifikasi karena tidak ada dua manusia memiliki sidik jari yang persis sama dan juga polanya selalu ada dalam setiap tangan dan bersifat permanen (Anonim, 2015). Bintik hitam setiap individu ikan kerapu bebek hasil pengamatan yang terfokus pada bagian abdomen terlihat adanya perbedaan, walaupun jumlah bintik hitam tidak berbeda, namun letak dan ukurannya nampak tidak sama (Gambar 2 \& 3). Selain itu, dengan bertambahnya umur dan ukuran ikan kerapu bebek tersebut, jumlah bintik hitam pada badannya juga bertambah dan belum ada informasi tentang sampai kapan jumlah bintik hitam tersebut stabil.

\section{Cacat Permanen (Abnormalitas)}

Selain dikenal sebagai ikan hias pada masa yuwana (tiga bulan setelah menetas), kerapu bebek merupakan ikan budidaya yang memiliki nilai keabnormalan paling tinggi. Dari setiap hasil pembenihan selalu ditemukan benih dengan kondisi tubuh tidak sempurna dan baru dapat diamati setelah melewati masa metamorfosis. Faktor penyebab dari kondisi tersebut, belum diketahui dengan jelas dan perlu dilakukan penelitian tersendiri untuk mengetahui faktor-faktor yang berperan dan memicu ketidaknormalan tersebut. Berdasarkan hasil pemantuan yang telah dilakukan, abnormalitas yang sering ditemukan antara lain: tubuh bengkok, mulut melengkung ke atas, insang terbuka (operkulum tidak sempurna), mata melotot, badan memendek (kerdil), sirip dorsal menyatu dengan sirip ekor dan kondisi ketidaknormalan lainnya (Gambar 4). Akan tetapi benih benih tersebut masih bertahan hidup jika pelihara dengan kondisi yang baik, namun tetap dengan kondisi badan yang cacat secara permanen.

\section{Perkembangan Gonad Kerapu Bebek Hasil Budidaya}

Secara global sebagian besar individu yang ada di bumi memiliki gonad yang berfungsi untuk mempertahankan populasinya dan meneruskan generasinya. Gonad akan berkembang seiring dengan penambahan umur dan peningkatan bobot badannya. Pada ikan kerapu hasil budidaya sangat diharapkan terbentuknya gonad dengan sempurna dengan tujuan untuk mengurangi penangkapan induk dari alam. Akan tetapi di lapangan sering ditemukan bahwa, sebagian besar induk ikan kerapu hasil budidaya yang telah diseleksi, belum bisa memijah alami secara sempurna. Pemijahan kerapu bebek di BBPPB Laut Gondol Bali mulai dirintis pada tahun 1995. Berbagai aspek telah diamati, mulai dari morfologi, reproduksi, pemijahan, benih, dan karakter genetiknya. Rintisan pemijahan induk hasil budidaya telah dilakukan selama kurun waktu 10 tahun. Akan tetapi sebagian besar belum berhasil memijah dan telur serta benih yang dihasilkan 95\% berasal dari pemijahan induk alam. Pada tahun 2010-2012, mulai dilakukan pemijahan silang antara induk alam (F0) dengan induk hasil budidaya dan telah menghasilkan benih F3 (Tridjoko et al., 2012). Berdasarkan hal tersebut, 

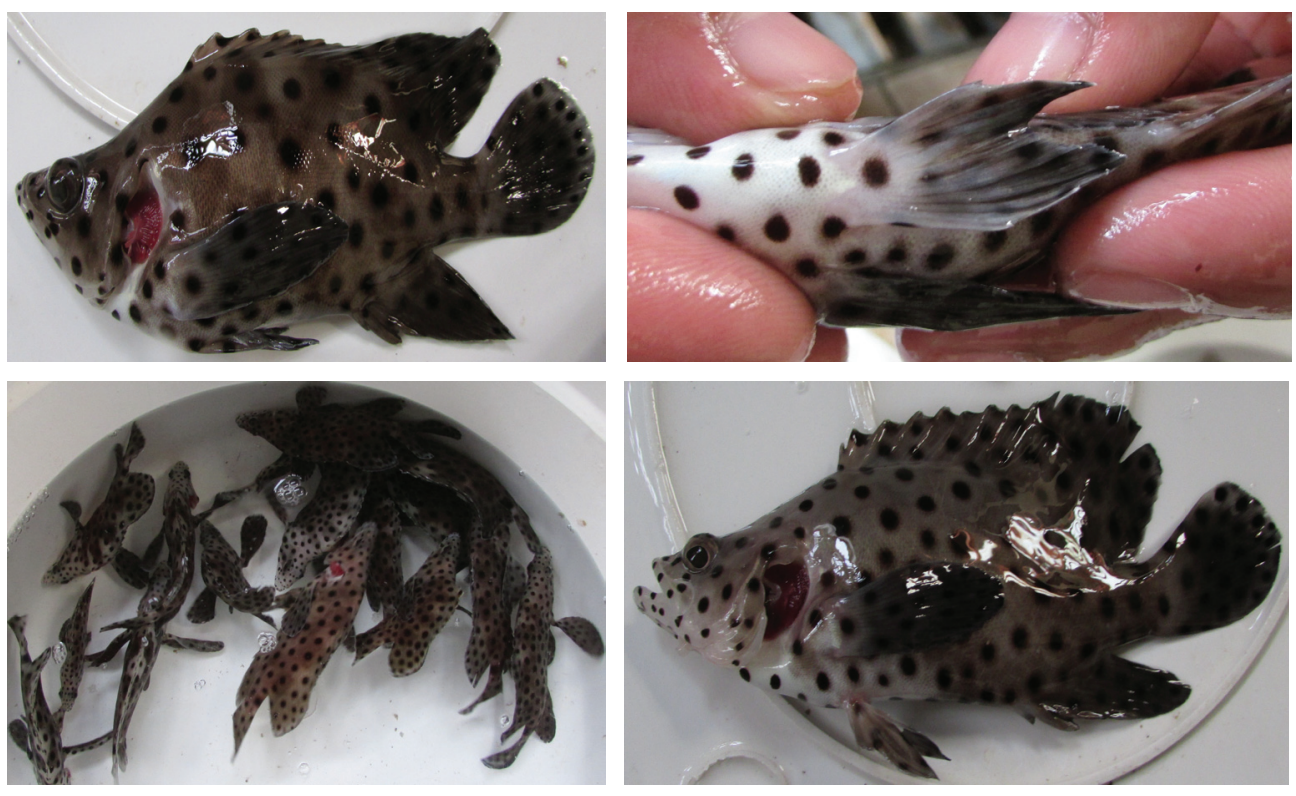

Gambar 4. Beberapa contoh abnormalitas benih kerapu bebek hasil budidaya

Figure 4. An example abnormality of humpback grouper from aquaculture

informasi tentang perkembangan gonad ikan kerapu bebek hasil budidaya dirasa perlu, karena pada periode yang akan datang, dapat ditemukan metode yang tepat untuk membantu mempercepat pembentukan gonad sehingga bisa dipijahkan tanpa tergantung induk alam. Dari pengamatan yang dilakukan pada calon induk kerapu bebek turunan pertama (F1) yang berumur sama ( \pm 30 bulan) dengan kisaran bobot badan $600-$ $900 \mathrm{~g}$ setelah dilakukan pembedahan, menunjukkan bahwa $90 \%$ calon induk kerapu bebek berkelamin betina sementara individu jantan dari 20 sampel uji hanya 1 ekor yang menunjukkan gonad jantan. Dengan demikian dapat dikatakan bahwa, calon induk kerapu bebek dengan bobot badan kurang dari $1.000 \mathrm{~g}$ sebagian besar adalah betina, sehingga untuk memijah dengan sempurna, diperlukan bantuan induk alam yang sudah memiliki fase jantan fungsional. Gambar 5 menampilkan gambaran gonad ikan kerapu bebek turunan pertama (F1) hasil seleksi.

Gambaran gonad pada Gambar 5 menginformasikan bahwa calon calon induk kerapu bebek hasil budidaya memiliki gonad yang sudah berkembang dan kemungkinan bisa atau siap memijah. Namun untuk membantu mempercepat pembentukan individu jantan diperlukan suatu rangsangan seperti implant hormone reproduksi atau memacu pertumbuhannya dengan pemberian pakan yang berkualitas (cumi-cumi, ikan atau kekerangan) dengan penambahan vitamin E yang dicampurkan pada pakan yang diberikan. Berdasarkan hasil penelitian Muzaki et al., 2012) dan Tridjoko et al. (2014b), dengan perlakuan implantasi beberapa jenis hormon reproduksi pada calon induk kerapu bebek turunan pertama (F1), pada akhir perlakuan diketahui bahwa, calon induk dengan perlakuan hormon dan kontrol masing-masing memijah dengan tingkat fekunditas berkisar 105.000-890.0000 butir telur dengan tingkat pembuahan masih rendah (20\% pada kontrol) dan (57\% pada perlakuan hormon). Pemijahan berlangsung selama lima hari pada perlakuan hormon, sementara pada perlakuan kontrol hanya berlangsung selama tiga hari dan sebagian besar hasil pemijahan hari kedua dan ketiga telur-telur mengendap di dasar (tidak terbuahi) (Tabel 2). Dari hasil observasi tersebut, dapat dikatakan bahwa calon induk kerapu bebek dari hasil budidaya, dapat memijah dengan baik, apabila dibantu dengan rangsangan hormonal atau pemberian pakan yang berkualitas dan kondisi lingkungan pemeliharaan yang stabil. Karena ikan kerapu bebek tersebut bersifat protogenus hermaprodit, di mana fase betina terbentuk lebih awal (Allsop \& West, 2003; Perry \& Grober, 2003), sehingga masih sulit memperoleh individu jantan dari populasi yang berumur dan memiliki kisaran bobot badan yang sama.

Dari gambaran telur hasil pemijahan calon induk kerapu bebek F1 (Gambar 6), terlihat bahwa telah terjadi pembuahan, namun tingkat pembuahan yang dihasilkan masih rendah dan kualitasnya masih di bawah standar, sehingga larva yang dihasilkan juga memiliki tingkat sintasan tidak sebaik dibanding hasil pemijahan induk alam. Berdasarkan data yang diperoleh dari kegiatan ini nampaknya penelitian yang lebih mengarah ke bidang pemuliaan atau genetik akan sangat mendukung guna mendapatkan informasi yang lebih akurat, sehingga kemungkinan untuk memiliki/menghasilkan induk dari hasil budidaya yang berkualitas baik fungsional jantan maupun betina dapat terpenuhi. 

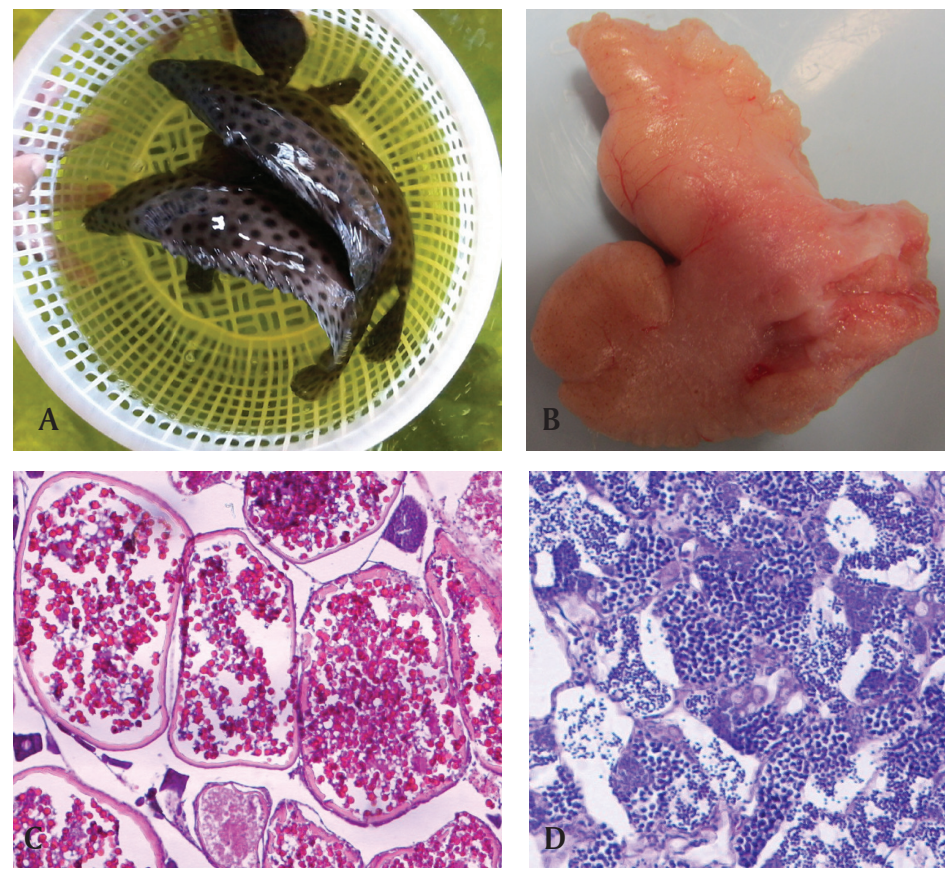

Keterangan :
A. Calon induk kerapu bebek F1 seleksi
B. Gonad betina
C. Histologi gonad betina
D. Histologi gonad jantan

Gambar 5. Calon induk, gonad serta histologi gonad jantan dan betina

Figure 5. Broodstock candidate, gonads, and histology of male and female gonads

Tabel 2. Pemijahan calon induk kerapu bebek hasil budidaya (F1)

Table 2. Broodstock candidate breeding of humpback grouper from aquaculture (F1)

\begin{tabular}{|c|c|c|c|c|c|}
\hline \multirow{3}{*}{$\begin{array}{c}\text { Bulan } \\
\text { Months }\end{array}$} & \multirow{3}{*}{$\begin{array}{l}\text { Perlakuan } \\
\text { Treatments }\end{array}$} & \multicolumn{3}{|c|}{ Pemijahan (Breeding) } & \multirow{3}{*}{$\begin{array}{l}\text { Keterangan } \\
\text { Description }\end{array}$} \\
\hline & & \multicolumn{2}{|c|}{ Jumlah telur (Number of eggs) } & \multirow{2}{*}{$\begin{array}{l}\text { Hatching rate } \\
\text { (\%) }\end{array}$} & \\
\hline & & Steril (Sterile) & Fertil (Fertile) & & \\
\hline \multirow[t]{2}{*}{ Oktober } & Hormonal & $369.000(43 \%)$ & $481.000(57 \%)$ & 45 & $\begin{array}{l}\text { Larva tidak ditebar } \\
\text { Larvae are not stocked }\end{array}$ \\
\hline & Kontrol (Control) & $74.700(78 \%)$ & $21.300(22 \%)$ & Tidak menetas (No hatch) & - \\
\hline \multirow[t]{2}{*}{ November } & Hormonal & $63.600(60.5 \%)$ & $41.400(39.4 \%)$ & 40 & $\begin{array}{l}\text { Larva mati pada umur } 11 \text { hari setelah menetas } \\
\text { Larvae dead at the age } 11 \text { days after hatching }\end{array}$ \\
\hline & Kontrol (Control) & - & - & - & Tidak memijah (Inbreeding) \\
\hline \multirow[t]{2}{*}{ Desember } & Hormonal & $159.500(20 \%)$ & $120.500(15 \%)$ & 35 & $\begin{array}{l}\text { Larva tidak ditebar } \\
\text { Larvae are not stocked }\end{array}$ \\
\hline & Kontrol (Control) & - & - & - & Tidak memijah (Inbreeding) \\
\hline
\end{tabular}

\section{KESIMPULAN}

Beberapa catatan yang dapat diperhatikan, untuk lebih mengenal lebih dekat komoditas kerapu bebek, sebelum dijadikan sebagai ikon jenis ikan yang pernah memiliki masa kejayaan, karena saat ini popularitasnya relatif menurun karena sudah masuk daftar CITES dan adanya larangan ekspor yang dikhawatirkan mengancam populasinya di alam. Dari hasil penelitian ini, maka dapat disimpulkan kerapu bebek selama fase yuwana (umur 2-3 bulan) dapat dijadikan sebagai kandidat ikan hias dengan performasi tubuh yang memiliki bintik hitam pada permukaan tubuhnya. Spot atau bintik hitam pada permukaan tubuh punya keunikan tersendiri, karena jumlah dan polanya berbeda antara satu individu dengan yang lainnya serta akan bertambah jumlahnya seiring dengan 

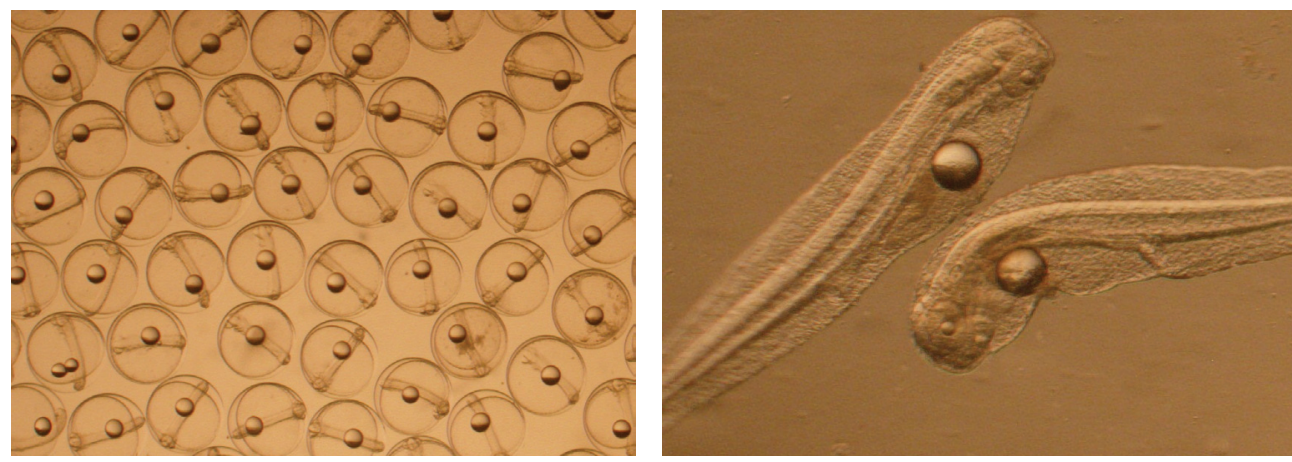

Gambar 6. Telur dan larva dari pemijahan kerapu bebek hasil budidaya (F1)

Figure 6. Eggs and larvae from breeding of humpback grouper culture (F1)

bertambahnya umur dan bobot badan. Spot/bintik hitam kemungkinan merupakan cirri spesifik dari kerapu bebek yang dapat digunakan sebagai unsur pembeda di antara individu dalam satu populasi. Gonad kerapu bebek turunan pertama (F1) dengan umur dan kisaran bobot badan yang kurang lebih sama (600-900 g), menunjukkan 95\% berada pada fase betina. Pematangan dan pembentukan gonad jantan pada kerapu bebek hasil budidaya dapat dipacu dengan rangsangan hormonal dan pemberian pakan segar dengan kualitas yang baik. Kerapu bebek hasil budidaya dapat memijah dengan baik dan menghasilkan turunan generasi kedua (F2), akan tetapi kualitas telur dan larva yang dihasilkan belum sebaik dari hasil pemijahan induk alam.

\section{DAFTAR ACUAN}

Allsop, D.J., \& West, S.A. (2003). Sex change life history invariants in fish. Journal of Evolutionary Biology, 16, 921-929.

Anonim. (2015). https://id. Wikipedia org/

Kincaid, H.L. (1983). Results from six generation of selection for accelerated growth rate in a rainbow trout population. Abstract. Fish Culture Selection of the American Fisheries Society, p. 26-27.

Muzaki, A., Tridjoko, Sembiring, S.B.M., Haryanti, \& Yudha, H.T. (2012). Produksi calon induk jantan dan betina ikan kerapu bebek (Cromileptes altivelis) dengan manipulasi hormon. Laporan teknis. Balai Besar Penelitian dan Pengembangan Budidaya Laut, Gondol. Bali, 21 hlm.
Perry, M.N., \& Grober, M.S. (2003). A model for social control of sex change: interaction of behavior, Neuropeptides, glucocorticoids, and sex steroid. Hormon and Behavior, 43, 31-38.

Tave, D. (1995). Slective breeding programmes for medium-sized fish farms. FAO Fisheries Technical Paper No. 352.

Tridjoko, Haryanti, Sembiring, S.B.M., Muzaki, A., \& Ismi, S. (2012). Performansi kematangan gonad dan pemijahan induk ikan kerapu bebek hasil perkawinan silang antara F2 dan F0. Laporan teknis. BBPPBL Gondol. Bali, $15 \mathrm{hlm}$.

Tridjoko, Wardana, I.K., Haryanti, Sembiring, S.B.M., \& Setiawati, K.M. (2013). Produksi massal benih ikan kerapu bebek (C. altivelis) hasil perkawinan antara induk betina hasil budidaya dan induk jantan dari alam (lanjutan). Laporan teknis BBPPBL Gondol. Bali, 17 hlm.

Tridjoko, Haryanti, Sembiring, S.B.M., Muzaki, A., \& Wardana, I.K. (2014a). Performansi kematangan gonad dan pemijahan induk ikan kerapu bebek hasil perkawinan silang antara F-2 dan F-0. ISOI dan Departemen Ilmu dan Teknologi Kelautan IPB, Bogor. Jurnal Ilmu dan Teknologi Kelautan Tropis, 6(1), 41-51.

Tridjoko, Wardana, I.K., Sembiring, S.B.M., Muzaki, A., \& Haryanti. (2014b). Pembesaran dan evaluasi calon induk Kerapu bebek (C. altivelis) turunan pertama. Laporan teknis BBPPB laut Gondol tahun 2014. 
